\title{
ADVANCES IN RESEARCH OF LODGING AND EVALUATION IN SUGARCANE
}

\author{
LI, X. ${ }^{1,2 \#}-$ LIN, S. H. ${ }^{2 \#}-$ HUANG, Q. Y. ${ }^{2}-$ LIANG, Q. ${ }^{2}-$ LI, Y. J. ${ }^{2}-$ YANG, L. T. ${ }^{1,2^{*}}-$ LI, Y. R. ${ }^{1,2^{*}}$ \\ ${ }^{1}$ Agricultural College, Guangxi University, Nanning 530005, China
}

${ }^{2}$ Key Laboratory of Sugarcane Biotechnology and Genetic Improvement (Guangxi), Ministry of Agriculture, Guangxi Key Laboratory of Sugarcane Genetic Improvement, Sugarcane Research Center, Chinese Academy of Agricultural Sciences, Sugarcane Research Institute, Guangxi Academy of Agricultural Sciences, Nanning 530007, China

${ }^{\#} L i, X$. and Lin, S. H. have contributed equally to this manuscript.

*Corresponding authors

e-mail: litao61@hotmail.com(Litao Yang); liyr@gxaas.net(Yangrui Li)

(Received $3^{\text {rd }}$ Apr 2019; accepted $23^{\text {rd }}$ Apr 2019)

\begin{abstract}
Sugarcane is the largest sugar crop in China and the world, and one of the important commercial crops in southern China. However, the influence of sugarcane lodging is more and more serious with increasing cane yield. After lodging, the plant growth and sugar accumulation in stalk was seriously affected, resulting in considerable losses in cane and sugar yield, and difficulty in machine operation in the field. At present, there is no perfect evaluation method for sugarcane lodging, and little has been done on research of related physiological and biochemical indexes, microscopic structures and so on although there have been some reports on the effects of sugarcane lodging. But there has been a lot of research on lodging in rice, corn and wheat, which could be referred for studying the resistance mechanism and evaluation method in sugarcane.
\end{abstract}

Keywords: lodging resistance, agronomic character, yield, sugar content, lignin, cellulose

\section{Introduction}

Guangxi Province had been ranking the first in sugarcane planting area, cane and sugar production, and economic benefit in China (Ye et al., 2016; Li, 2010). With tall plant and large biomass above ground, at the late elongation and maturation stages after October, the plant height of sugarcane exceeds $300 \mathrm{~cm}$, the higher the plant is, the greater the risk of lodging meets (Li et al., 2018a). After lodging, the cane yield and sugar content was declined, the photosynthesis, water metabolism, mineral absorption and conversion in plants, and mechanical and hand harvesting were also affected. The relationships between lodging and lignin, cellulose and microscopic structure were closely correlated.

\section{Cause of lodging}

Lodging is the phenomenon that crop stem changes from natural upright state to permanent dislocation. Wind and rain were the direct induction factor for lodging. In addition, environmental factors and cultivation measures also played a role in lodging (Merugumala et al., 2019; Ishimaru et al., 2008). According to the occurrence location, lodging was generally divided into two types: root lodging and stem lodging (Tian et al., 2016). Root lodging referred to whole-plant falling down when the load above ground exceeds the misspecified strength of the root system, and stem lodging referred 
to base stem breaks when the load on the upper part of the stem exceeds the mechanical support power of the base stem (Mizuno et al., 2018; Mulsanti, et al., 2018). For rice, stem lodging occurs frequently because the mechanical strength of the stem was weakened due to the weak base of the stem and the underdeveloped mechanical tissue (Sowadan et al., 2018; Li, 2012).

\section{Effect of lodging on agronomic characters}

The lodging of sugarcane was affected by the number of leaves, planting furrow depth, planting density, row spacing and other factors (Singkham et al., 2016). Park et al. (2005) and Cock et al. (1997) found that the relationship between the number of sugarcane leaves and sugarcane yield and lodging was closely related. The results showed that the lodging of sugarcane decreased after removing leaves due to the reduction of wind area, and the lodging of sugarcane decreased with the decline of sugarcane leaves. Meanwhile, each sugarcane plant remaining 4 to 6 leaves could ensure yield and effectively reduce lodging. Berding et al. (2005) conducted a comparative experiment on sugarcane planting with different planting depths and varieties. The results showed that the lodging of sugarcane was less when the row spacing was at $260 \mathrm{~mm}$, the sugarcane was prone to lodging when the row spacing was at $120 \mathrm{~mm}$, and there was less lodging in Q152 than Q187 and Q174. Babu et al. (2010) conducted an experiment to study on the relationship between hardness of sugarcane peel and lodging, and the results showed that sugarcane with high hardness of sugarcane peel was not easy to get lodging. By adding silicon fertilizer, the hardness of sugarcane epidermis could be effectively strengthened, so that the stalk could obtain good supporting force and the lodging rate could be reduced (Brienzo et al., 2014). Loganandhan et al. (2013) conducted a comparative experiment on planting depth and earth-up condition of sugarcane, and the results showed that deep planting could reduce lodging of sugarcane. Sugarcane was not prone to lodging when the number of seedcane buds and millable stems were controlled (Neto et al., 2018). Chiluwal et al. (2018) found that it was useful for improving the lodging resistance when the planting row spacing was more than $1 \mathrm{~m}$.

\section{Effect of lodging on cane yield}

Different degrees of lodging had different effects on sugarcane growth. For slightly inclined and semi-inclined sugarcane, their growth have been affected because the plant head was loosened and some sugarcane roots are broken, the sugarcane plants have to grow in bending (Heerden et al., 2014; Singh et al., 2002). For inclined and lodging sugarcane, their stem tips grow upward because sugarcane plants strive for gaining more sunlight, so that the meristematic tissue outside the region of growth on the sugarcane node proliferates rapidly, resulting in tender, fragile, bending and easybroken outer parts (Paraskevopoulos et al., 2016). The serious lodging causes the sugarcane plant to turn over, break or stop growing. If things go on liked this, the sugarcane stem would become dry. Moreover, rats liked to nest in the sugarcane bushes and steal sugarcane in large quantities. In addition, it was hard to conduct field management after sugarcane lodging, so the early lodging not only caused losses at that time, but also affected the later growth and reduces the cane yield due to the failure to fertilize and control pests such as aphids (Yang et al., 2016). Even worse, the perennial 
root of sugarcane could not be reserved for the next year after lodging due to root breakage, stool turnover, heavy damage in sugarcane stool, excessive nutrient consumption and rotten sugarcane stool with many germs, most sugarcane stools remaining perennial roots for the next year would have no buds to sprout, which resulted in plant deficiency and yield reduction in the ratoon crops (Shanmuganathan, et al., 2017).

\section{Effect of lodging on sucrose content}

The growth of sugarcane would be inhibited in root and tip after lodging, and sugarcane plants would be stacked together to give out heat. Together with sufficient water after rain, the root region of sugarcane stem germinated into air roots and lateral buds germinate (Jacobsen et al., 2015). Furthermore, the part above ground was exposed after lodging. When the sun shined directly, soil temperature would increase, resulting in the increase of ineffective tillers in later stage, nutrient consumption, hollow stem, decline of sucrose content, dry sugarcane plant and stem gradually that turned over or broke, rapid conversion of sugar and decline of sugar yield rate (Mcintyre et al., 2015). Therefore, the dry sugarcane stems not only are absorbed sugar content, but also increase the acidity of sugarcane juice while making sugar, which makes it difficult to make sugar and causes certain losses to factories (Singh, 2002).

Sucrose is the main form of carbohydrate transport in sugarcane plants. However, sugarcane plants after lodging have weak photosynthetic capacity, less carbohydrate synthesis and insufficient sunlight, which affect transportation, slow down the sugar accumulation in segmental storage tissues, so that the brix of sugarcane juice was low at harvest time. For instance, sugarcane plants lodged in late September had a full-stem brix $6.13 \%$ lower than that of normal plants when harvesting in January next year, and the lower segment was the area where sugar accumulation was seriously affected (Huang, et al., 2014).

\section{Effect of lodging on physiological and biochemical indexes}

Sugarcane was a $\mathrm{C}_{4}$ plant with high photosynthetic intensity and light saturation point (Marchiori et al., 2014). After lodging of sugarcane plants, the leaves could not obtain sufficient light energy due to the deterioration of light conditions in the field, which could not meet the direct needs of photosynthesis for light energy, but also hinder the stomatal opening, increased the diffusion resistance of $\mathrm{CO}_{2}$ into the leaves and reduce the photosynthetic intensity significantly (Liu et al., 2016a). Moreover, lodging was also not conducive to leaf extension. Zhao et al. (2014) reported that the average leaf area and single stem green leaf area of sugarcane plants after lodging declined by $25.3 \%$ and $22.7 \%$ respectively compared with normal plants. The reduction of photosynthetic area would inevitably lead to the decrease of synthetic amount of photosynthetic product in the whole sugarcane plant (Mo, 1979).

The water metabolism of sugarcane plants is composed of three closely-related links: water absorption, water transport and water loss, and there are two mechanisms of water absorption in sugarcane plants: active absorption and passive absorption (Jangpromma et al., 2010). After lodging of sugarcane plants, some of the roots are broken by mechanical force and the root system could not get enough carbohydrates from the ground, so the activity of life is weak and the amount of active water absorption 
decreases (Zhang et al., 2015). Meanwhile, sugarcane plants after lodging are squeezed together with weak light and high relative humidity, as well as weak transpiration, which greatly affect the passive water absorption ability. Since the water absorption and loss (mainly transpiration) of sugarcane plants after lodging are adversely affected, water transport has to proceed gradually, which destroys the normal water metabolism of sugarcane plants and is extremely harmful to their growth and tissue enrichment (Heerden et al., 2015).

After lodging of sugarcane plants, the life activities of root system are adversely affected, and the absorption and transport of mineral nutrients are weakened. According to Chand et al. (2010), the amount of potassium chloride absorbed by the root system of sugarcane plants after lodging and transported by xylem to parts above ground was about half of that of normal plants, and the amount of phosphorus was only $1 / 4$ of that of normal plants. After lodging, the normal physiological condition of phosphorus and potassium absorption and transport from outside during the whole growth process of sugarcane plants was changed obviously, which was an important reason for poor growth, low yield and poor quality (Yanai et al., 2010).

\section{The relationship between lodging and lignin and cellulose}

During the period of internode enrichment, a large number of photosynthetic products would flow to the stem, and the cell wall is significantly thicker accompanied by fibrosis and lignification. In the mean time, a large amount of starch accumulated in parenchyma cells significantly increases the dry weight per unit length of stem, which is the key period to determine lodging resistance (Ferreira et al., 2016).

\section{Lignin}

As a phenolic polymer synthesized from cinnamon alcohol and other monomers, lignin is the organic component next only to cellulose on the earth, which has a relatively high content in wood plants, generally accounting for $15 \%$ to $35 \%$ of dry weight (Stewart et al., 2015). With the biological functions of strengthening the mechanical strength of cell wall, improving transport capacity of cells and resisting microbial invasion, lignin exists in the cell walls of tracheids and xylem vessels of various supporting and leading tissues in plants, which is mainly accumulated in the thickened secondary cell wall, cross-linked and arranged with cellulose and hemicellulose (Zhao et al., 2015; Cao et al., 2015). The initial properties of lignin could enhance the hardness of stem and leading tissue so as to maintain the upward growth of plants and the upward transport of water and nutrients through the xylem (Kanran et al., 2018; Tian et al., 2017). Although lignin could improve the mechanical strength and stress tolerance of the stem, its content was closely related to the rigidity of the stem (Hu et al., 2017a), so the varieties with strong lodging resistance had high lignin content. Hasan et al. (1993) reported that there was no significant correlation between lodging resistance and lignin content in different types of rice varieties, but it was generally believed that lignin content significantly affected the mechanical strength of plant stems based on a large number of studies on rice, wheat and maize (Zhang et al., 2017; Kamran et al., 2018a, b). 


\section{Cellulose}

As the main component of plant skeleton (cell wall), the basic structural unit of cellulose is microfibril, and the content of cellulose affects the degree of thickening of cell wall and further determines the mechanical strength of stem (Hoang et al., 2017; William et al., 2017). For example, Wang et al. (2006) showed that the stem strength of wheat variety was significantly higher than that of its parents, which mainly attributed to higher cellulose content. Subsequently, Wang et al. (2012) and Liu et al. (2016b) drew the similar conclusion in wheat, soybean and rice respectively. Recently, Okuno et al. (2014) considered that, the adverse effect of insufficient lignin content on stem hardness could be compensated by increasing cellulose content so as to improve the lodging resistance of forage rice, which might result from the molecular compensation mechanism in the bio-synthesis pathway of cellulose and lignin. According to Robertson et al. (2017), the contribution of cellulose content under panicle internodes to maize stem reached by $85 \%$, which was in accordance with the study of Ma et al. (2012), indicating that it was an important method to improve the physical strength of maize stem and enhance the lodging resistance of maize by increasing cellulose content. Hernández et al. (2018) showed that the lodging rate of maize was negatively correlated with the crude fiber content of stem.

\section{The relationship between lodging and microscopic structure}

At present, there is no report about analysis of microscopic structure with sugarcane lodging, but a lot of research has been done on crops such as maize and rice (Tian et al., 2015; Du et al., 2016). From the perspective of cytology, the mechanical strength of stem mainly came from thick-walled cells, and plant cell walls were divided into primary and secondary walls. Wang et al. (2015) studied the morphological structure in stem, anatomical characteristics and chemical composition of cell wall of 10 maize varieties, and analyzed the correlation between these variables. The results shown that the cortex/radius, thick-walled tissue ratio, mechanical tissue ratio, cellulose content and lignin content of stem were positively correlated with stress tolerance, while the thickwalled tissue ratio, stem length/stem diameter and number of vascular bundles were negatively correlated with stress tolerance. According to Liu et al. (2011), the arrangement of rapeseed longitudinal xylem cells in the main stem of lodging resistant variety was relatively neat, which was distributed in a linear manner parallel to the main stem, the length-width ratio of most horizontal cortical cells was greater than two with compact and ordered arrangement, and the ray of vascular column penetrated the cambium. However, a material with common lodging resistance had irregular longitudinal arrangement of xylem cells, the length-width ratio of most horizontal cortical cells was less than the two with disordered arrangement, and the ray of vascular column had poor coherence with extra-cambium cells.

\section{Evaluation methods of lodging resistance in crops}

Crop lodging is the result of plant itself and environmental factors, and there are significant differences in lodging resistance in different crop genotypes, but the phenotypic identification of crop lodging resistance could only be carried out under certain environmental conditions. However, since the environmental conditions could 
not be accurately predicted, it is necessary to establish a mechanical evaluation system based on the physical and morphological characteristics of the plant itself, which is not depended on climate conditions, so could better evaluate the lodging resistance of crops (Corbin et al., 2014; Tian, 2013).

\section{Tilting angle method}

Tilting angle method (Zhang et al., 1999) is to show the lodging resistance of plants by the angle between the stem at the mature stage and the vertical line of the ground. According to tilting angle, degree of lodging could be divided into 3 types: lodging type (60-90 degrees), inclined type (30-60 degrees) and vertical type (0-30 degrees).

\section{Bending moment method}

When discussing the lodging resistance of rice with different panicle types, the bending moment method could be adopted (Xu et al., 2004).

\section{Resistance force method}

In this method, the dynamometer is placed vertically with the stem and $20 \mathrm{~cm}$ away from the ground. Then, the dynamometer is pushed slowly to an angle of $45^{\circ}$ between the plant and the ground, so the value showed by the instrument is the bending resistance of the stem. The larger the value is, the stronger the lodging resistance is. Otherwise, the worse the lodging resistance is. The advantage of this method is to evaluate the lodging resistance of rice by measuring the bending resistance of each stem, which was close to the real situation in the field ( $\mathrm{Li}$ et al., 2018b; Xiao et al., 2015).

\section{Lodging resistance index method}

Sun (1987) proposed an acknowledged formula: rice stem lodging resistance index (CLRI), it was calculated with basal stem resistance, stem length and grain weight per panicle. According to this formula, the lodging resistance of rice stem could be divided into four types, that is, none lodging resistant, more lodging resistant, lodging resistant and high lodging resistant. The higher the CLRI was, the greater the lodging resistance was, and vice versa ( $\mathrm{Li}, 2015)$.

\section{Application of the lodging resistance index}

Among the above anti-lodging evaluation methods, the lodging resistance index method is used most frequently, which can effectively reflect severity of corn lodging and yield after harvesting (Chu et al., 2017). Zhao et al. (2017) selected the best combination of silicon application amount by using the anti-lodging index. Zhang et al. (2019) and $\mathrm{Hu}$ et al. (2017b) found that lodging resistance coefficient of maize and wheat was closely related to stem folding resistance. Hu et al. (2018) found in the wheat comparative experiment that the four lodging indexes were all significantly positively 
correlated with the length of the second and third stem segments, and the lodging indexes bending moment and resistance force showed better effects.

\section{Conclusion}

After sugarcane lodging, its cane yield and sugar content would reduce seriously. Meanwhile, it reduces the quality of mechanical harvesting, go against to photosynthesis, make destruction of water metabolism, affects mineral absorption and conversion. Lignin and cellulose affect the degree of thickening of cell wall and further determine the mechanical strength of stem. The mechanical strength of stem mainly come from thick-walled cells. There are a lot of evaluation methods of lodging resistance in crops, and lodging resistance index method is used most frequently. It could be used for reference in sugarcane.

Acknowledgements. This research was supported by the Fund for the Guangxi Innovation Teams of Modern Agriculture Technology (gjnytxgxcxtd-03), Fund of Guangxi (2016GXNSFBA380138), Fund of Guangxi Science and Technology Base and Special Foundation (AD17195100), Funds of Guangxi Academy of Agricultural Sciences (2015JZ93, 2015YT02; G2014YZ01).

\section{REFERENCES}

[1] Babu, C., Koodalingam, K., Natarajan, U. S. (2010): Genetic enhancement of sugarcane (saccharum sp. hybrids) for resistance to red rot disease and economic traits. - Research Gate 4(3): 97-107.

[2] Berding, N., Hurney, A. P. (2005): Environmental stimuli promoting sucker initiation in sugarcane. - Hurneyd Field Crops Research 92(2): 219-230.

[3] Brienzo, M., Ferreira, S., Vicentim, M. P., Souza, W. D., Sant'Anna, C. (2014): Comparison study on the biomass recalcitrance of different tissue fractions of sugarcane culm. - Bioenergy Research 7(4): 1454-1465.

[4] Cao, C., Yang, Z., Han, L., Jiang, X., Ji, G. (2015): Study on in situ analysis of cellulose, hemicelluloses and lignin distribution linked to tissue structure of crop stalk internodal transverse section based on FTIR microspectroscopic imaging. - Cellulose 22(1): 139149.

[5] Chand, M., Lal, R., Khippal, A., Singh, R., Narang, A. K. (2010): Drought management in sugarcane during pre-monsoon period. - Sugar Tech 12(1): 64-66.

[6] Chiluwal, A., Singh, H. P., Sainju, U., Khanal, B., Whitehead, W. F., Singh, B. P. (2018): Spacing effect on energy cane growth, physiology, and biomass yield. - Crop Science 58(3): $1-14$

[7] Chu, T. X., Michael, J. S., Michael, J. B., Seth, C. M., Luke, S. P. (2017): Assessing lodging severity over an experimental maize (Zea mays L.) field using UAS images. Remote Sensing 9(9): 923-946.

[8] Cock, J. H., Amaya, A., Bohorquez, C., Munchmeyer, B. (1997): Simulation of production potential of self-defoliating sugarcane cultivars. - Field Crops Research 54: 18.

[9] Corbin, J. L. (2014): Evaluation of management practices to mitigate lodging for 'cl151' rice (Oryza sativa, L.). - Mississippi State University Dissertations \& Theses. Gradworks 1: 22-23.

[10] Du, J., Zhang, Y., Guo, X., Ma, L., Shao, M., Pan, X., Zhao, C. (2016): Micron-scale phenotyping quantification and three-dimensional microstructure reconstruction of 
vascular bundles within maize stalks based on micro-CT scanning. - Functional Plant Biology 44: 10-22.

[11] Ferreira, S. S., Hotta, C. T., Poelking, V. G. D. C., Leite, D. C. C., Buckeridge, M. S., Loureiro, M. E. (2016): Co-expression network analysis reveals transcription factors associated to cell wall biosynthesis in sugarcane. - Plant Molecular Biology 91(1-2): 1535.

[12] Hasan, S., Shimojo, M., Goto, I. (1993): Chemical components influencing lodging resistance of rice plant and its straw digestibility in vitro. - Asian-Australasian Journal of Animal Sciences 6: 41-44.

[13] Heerden, P. D. R. V. (2014): Effects of lodging and anti-lodging chemicals on the productivity of variety N25: preliminary findings. - Proceedings of South African Sugar Technologists' Association 84: 169-172.

[14] Heerden, P. D. R. V., Singels, A., Paraskevopoulos, A., Rosslera, R. (2015): Negative effects of lodging on irrigated sugarcane productivity. An experimental and crop modelling assessment. - Field Crops Research 180: 135-142.

[15] Hernández, A. J. M., Largo, G. A., Martínez, R. R., Pereda, D., Álvarez, J. M., Acebes, J. L. (2018): Effect of ancymidol on cell wall metabolism in growing maize cells. - Planta 247(4): 987-999.

[16] Hoang, N. V., Furtado, A., O'Keeffe, A. J., Botha, F. C., Henry, R. J. (2017): Association of gene expression with biomass content and composition in sugarcane. - PloS ONE 12(8): 8-14.

[17] Hu, D., Liu, X. B., She, H. Z., Gao, Z., Ruan, R. W., Wu, D. Q., Yi, Z. L. (2017a): The lignin synthesis related genes and lodging resistance of Fagopyrum esculentum. Biologia Plantarum 61(1): 138-146.

[18] Hu, H., Li, S. S., Hua, H., Sun, M. M., Kang, J., Xiang, G. J., Wang, C. Y. (2017b): Research on stalk morphological structure characteristics and its relationship between with the lodging of different wheat varieties. - Journal of Triticeae Crops 10: 83-88.

[19] Hu, W. G., Cao, T. J., Wang, X. C., Zhang, Y. E., Chang, P., Zhan, H. (2018): Qualitative and quantitative study on lodging resistance of wheat varieties in Henan Province. - Acta Agriculturae Boreali-Sinica 33(05): 164-171.

[20] Huang, W. W., Li, W. J., He, G. B., Pan, T. Y., Han, L. X., Luo, F. F. (2014): Regional trial reports on sugarcane varieties in Baise, Guangxi (2011-2012). - Journal of Southern Agriculture 45(2): 194-199.

[21] Ishimaru, K., Togawa, E., Ookawa, T., Kashiwagi, T., Yuka, M., Naoki, H. (2008): New target for rice lodging resistance and its effect in a typhoon. - Planta 227(3): 601-609.

[22] Jacobsen, K. R., Fisher, D. G., Maretzki, A., Moore, P. H. (2015): Developmental changes in the anatomy of the sugarcane stem in relation to phloem unloading and sucrose storage. - Plant Biology 105(1): 70-80.

[23] Jangpromma, N., Kitthaisong, S., Lomthaisong, K., Daduang, S., Jaisil, P., Thammasirirak, S. (2010): A proteomics analysis of drought stress-responsive proteins as biomarker for drought-tolerant sugarcane cultivars. - American Journal of Biochemistry \& Biotechnology 6(2): 89-102.

[24] Kamran, M., Ahmad, I., Wang, H., Wu, X., Jing, X., Liu, T., Ding, R., Han, Q. (2018a): Mepiquat chloride application increases lodging resistance of maize by enhancing stem physical strength and lignin biosynthesis. - Field Crops Research 224: 148-159.

[25] Kamran, M., Ahmad, I., Wu, X., Liu, T., Ding, R., Han, Q. (2018b): Application of paclobutrazol: a strategy for inducing lodging resistance of wheat through mediation of plant height, stem physical strength, and lignin biosynthesis. - Environmental Science and Pollution Research 25(29): 366-378.

[26] Li, F., Liu, S., Xu, H., Xu, Q. (2018b): A novel fc17/cesa4 mutation causes increased biomass saccharification and lodging resistance by remodeling cell wall in rice. Biotechnology for Biofuels 11(1): 298-306. 
[27] Li, H. (2012): Mechanical model with varying stiffness and critical grain load of wheat stalk. - Transactions of the Chinese Society for Agricultural Machinery 43(2): 70-74.

[28] Li, X., Li, Y. J., Liang, Q., Lin, S. H., Huang, H. R., Huang, Q. Y. (2018a): Adaptability of sugarcane clone in Nanning ecological region. - Guangxi Sugar Industry 22: 129-130.

[29] Li, Y., Liu, G., Li, J., You, Y. L., Zhao, H. M., Liang, H., Mao, P. (2015): Acid detergent lignin, lodging resistance index, and expression of the caffeic acid O-methyltransferase gene in brown midrib-12 sudangrass. - Breeding Science 65(4): 291-297.

[30] Li, Y. R. (2010): Modern Sugarcane Science. - China Agriculture Press, Beijing, pp. 121122.

[31] Liu, T., Liu, W. G., Ren, M. L., Du, Y. L., Deng, Y. C., Zou, J. L. (2016a): Effects of shade degrees on photosynthesis and lodging resistance degree of different shade tolerance soybean. - Scientia Agricultura Sinica 49(8): 1466-1475.

[32] Liu, T. X., Guan, C. Y., Li, Y. X. (2011): Prelimilary study on the relationship between stem microstructure and lodging resistance in rapeseed (Brassica napes L.). - Chinese Agricultural Science Bulletin 27(5): 139-143.

[33] Liu, W., Deng, Y., Hussain, S., Zou, J., Yuan, J., Luo, L., Yang, C., Yuan, X., Yang, W. (2016b): Relationship between cellulose accumulation and lodging resistance in the stem of relay intercropped soybean [Glycine max (1.) Merr.]. - Field Crops Research 196: 261267.

[34] Loganandhan, N., Gujja, B., Goud, V. V. (2013): Sustainable sugarcane initiative (SSI): a methodology of 'more with less'. - Sugar Tech 15(1): 98-102.

[35] Ma, Y. H., Sun, D. Q., Li, T. Y., Lin, H., Pan, L. Y., Zhang, C. Y. (2012): Correlation analysis between rind penetration resistance and morphological characters and chemical conents in maize stalk. - Heilongjiang Agricultural Sciences 4: 1-4.

[36] Marchiori, P. E. R., Machado, E. C., Ribeiro, R. V. (2014): Photosynthetic limitations imposed by self-shading in field-grown sugarcane varieties. - Field Crops Research 155: 30-37.

[37] Mcintyre, C. L., Goode, M. L., Cordeiro, G., Bundock, P., Eliott, F., Henry, R. J. (2015): Characterisation of alleles of the sucrose phosphate synthase gene family in sugarcane and their association with sugar-related traits. - Molecular Breeding 35(3): 1-14.

[38] Merugumala, G. R., Satyanarayana, P. V., Narne, C., Ravikumar, B. N. V. S. R., Ramana, R. P. V., Pavani, L., Deepika, V. (2019): Molecular breeding of "swarna," a mega rice variety for lodging resistance. - Molecular Breeding 39(4): 39-55.

[39] Mizuno, H., Kasuga, S., Kawahigashi, H. (2018): Root lodging is a physical stress that changes gene expression from sucrose accumulation to degradation in sorghum. - BMC Plant Biology 18(1): 1-12.

[40] Mo, J. Y. (1979): Preliminary analysis of adverse physiological effects of sugarcane lodging. - Sugar Industry 12: 22-24.

[41] Mulsanti, I. W., Yamamoto, T., Ueda, T., Samadi, A. F., Kamahora, E., Rumanti, I. A., Thanh, V. C., Adachi, S. (2018): Finding the superior allele of japonica- type for increasing stem lodging resistance in indica rice varieties using chromosome segment substitution lines. - Rice 11(1): 1-14.

[42] Neto, J. R., Souza, Z. M. D., Kölln, O. T., Carvalho, J. L. N., Ferreira, D. A., Barbosa, L. C. (2018): The arrangement and spacing of sugarcane planting influence root distribution and crop yield. - Bioenergy Research 4: 1-14.

[43] Okuno, A., Hirano, K., Asano, K., Takase, W., Masuda, R., Morinaka, Y., Ueguchi, T. M. (2014): New approach to increasing rice lodging resistance and biomass yield through the use of high gibberellin producing varieties. - PLoS ONE 9: 1-5.

[44] Paraskevopoulos, A. L., Singls, A. L., Tweddle, P. B. (2016): Quantifying the negative impact of lodging on irrigated sugarcane productivity: a crop modelling assessment. Africa Sugarcane Technology 89: 154-158. 
[45] Park, S. E., Robertson, M., Inmanbamber, N. G., Inmanbamber, N. G., Bonnett, G. D., Thorburn, P. J. (2005): Decline in the growth of a sugarcane crop with age under high input conditions. - Field Crops Research 92(2): 305-320.

[46] Robertson, D. J., Julias, M., Lee, S. Y., Cook, D. D. (2017): Maize stalk lodging: morphological determinants of stalk strength. - Crop Science 57(2): 926.

[47] Shanmuganathan, M., Baskaran, V., Chandrasekaran, R. (2017): Evaluation of mid-late sugarcane clones for their yield and quality characters in advanced selection stage in plant and ratoon crops. - Electronic Journal of Plant Breeding 8(3): 992-997.

[48] Singh, G. (2002): Constraints to high yield and CCS in large and lodged cane crops. $\mathrm{Ph} . \mathrm{D}$. Thesis of James Cook University, Queensland, pp. 28-30.

[49] Singh, G., Chapman, S. C., Jackson, P. A., Lawn, R. J. (2002): Lodging reduces sucrose accumulation of sugarcane in the wet and dry tropics. - Australian Journal of Agricultural Research 53(11): 1183.

[50] Singkham, N., Songsri, P., Jaisil, P. (2016): Diversity of characteristics associated with lodging resistance in sugarcane germplasm. - Sabrao Journal of Breeding Genetics 48: 97-104.

[51] Sowadan, O., Li, D., Zhang, Y., Zhu, S., Hu, X., Bhanbhro, L. B., et al. (2018): Mining of favorable alleles for lodging resistance traits in rice (Oryza sativa) through association mapping. - Planta 248(1): 155-169.

[52] Stewart, C. E., Moturi, P., Follett, R. F., Halvorson, A. D. (2015): Lignin biochemistry and soil $\mathrm{n}$ determine crop residue decomposition and soil priming. - Biogeochemistry 124(1-3): 335-351.

[53] Sun, X. C. (1987): Study on the resistance of the culm of rice to lodging. - China Agriculture Science 20(4): 32-37.

[54] Tian, B., Liu, Y., Zhang, L., Li, H. (2017): Stem lodging parameters of the basal three internodes associated with plant population densities and developmental stages in foxtail millet (Setaria italica) cultivars differing in resistance to lodging. - Crop Pasture Science 68(4): 349-357.

[55] Tian, B. H. (2013): The methods of lodging resistance assessment in cereal crops and their application in foxtail millet. - Journal of Plant Genetic Resources 14(2): 265-269.

[56] Tian, B. H., Liu, L. Y., Zhang, L. X., Song, S. X., Wang, J. G., Wu, L. F. (2015): Characterization of culm morphology, anatomy and chemical composition of foxtail millet cultivars differing in lodging resistance. - Journal of Agricultural Science 153(8): 1437-1448.

[57] Tian, Z. M., Huang, Z. H., Chen, J. X., Shi, B. L., Wei, D., Zhai, W. H., Li, H. (2016): Effects of planting density on lodging resistance and yield of three erectophile maize varieties. - Journal of Maize Sciences (5): 83-88.

[58] Wang, J., Zhu, J. C., Lin, Q. Q., Li, X. J., Teng, N. J., Li, Z. S., Li, B., Zhang, A. M., Lin, J. X. (2006): The effect of stem structure and cell wall chemical composition on the stress resistance of wheat stem. - Chinese Science Bulletin 51(6): 679-685.

[59] Wang, J., Zhu, J., Huang, R., Yang, Y. S. (2012): Investigation of cell wall composition related to stem lodging resistance in wheat (Triticum aestivum L.) by FTIR spectroscopy. - Plant Signaling Behavior 7(7): 856-863.

[60] Wang, T. J., Zhang, L., Han, Q. (2015): Effects of stalk cell wall and tissue on the compressive strength of maize. - Plant Science Journal 33(1): 109-115.

[61] William, P. B., Heather, D. C. (2017): Cell wall composition and lignin biosynthetic gene expression along a developmental gradient in an Australian sugarcane cultivar. - Peer J 5: 4141.

[62] Xiao, Y., Liu, J., Li, H., Cao, X., Xia, X., He, Z. (2015): Lodging resistance and yield potential of winter wheat: effect of planting density and genotype. - Frontiers Agricultural Science and Engineering 2(2): 168-177. 
[63] Xu, Z. J., Chen, W. F., Ma, D. R., Lu, Y. N., Zhou, S. Q., Liu, L. X. (2004): Correlations between rice grain shapes and main qualitative characteristics. - Acta Agronomica Sinica 30(9): 894-900.

[64] Yanai, J., Nakata, S., Funakawa, S., Nawata, E., Katawatin, R., Kosaki, T. (2010): Effect of NPK application on growth, yield and nutrient uptake by sugarcane on a sandy soil in northeast Thailand. - Tropical Agriculture Development 54: 113-118.

[65] Yang, W., Mo, X. W., Yang, J., Yuan, F. W., Huang, S. C. (2016): Experimental study on the basic parameters of sugarcane on easy lodging period - Journal of Agricultural Mechanization Research 12: 143-148.

[66] Ye, J., Yang, Y. Y., Xu, L. P., Li, Y. R., Que, Y. X. (2016): Economic impact of stem borer-resistant genetically modified sugarcane in Guangxi and Yunnan provinces of China. - Sugar Tech 18(5): 1-9.

[67] Zhang, F. J., Zhang, K. K., Du, C. Z., Li, J., Xing, Y. X., Yang, L. T., Li, Y. R. (2015): Effect of drought stress on anatomical structure and chloroplast ultrastructure in leaves of sugarcane. - Sugar Tech 17(1): 41-48.

[68] Zhang, H. N., Yu, Q., Du, X. Y., Liu, M. Q., Xu, E. J., Liu, Z. Q. (2019): The effect of straw mulching and pre-sowing irrigation on resistance of summer maize against lodging. - Journal of Irrigation and Drainage 38(2): 9-14.

[69] Zhang, W., Wu, L., Ding, Y., Yao, X., Wu, X., Weng, F., Li, G., Liu, Z., Tang, S., Ding, C., Wang, S. (2017): Nitrogen fertilizer application affects lodging resistance by altering secondary cell wall synthesis in japonica rice (Oryza sativa). - Journal of Plant Research 130(5): 1-13.

[70] Zhang, Z. X., Chen, W. F., Yang, Z. Y., Hua, Z. T., Gao, R. L., Gao, Y., Zhao, Y. C. (1999): Effect of lodging resistance on yield and its relationship with stalk physical characteristics. - Journal of Shenyang Agricultural University 30(2): 81-85.

[71] Zhao, D., Glaz, B., Irey, M. S., Hu, C. J. (2014): Sugarcane genotype variation in leaf photosynthesis properties and yield as affected by mill mud application. - Agronomy Journal 107(2): 506-517.

[72] Zhao, Q., Zeng, Y., Yin, Y., Pu, Y., Jackson, L. A., Engle, N. L., Martin, M. Z., Tschaplinski, T. J., Ding, S. Y., Ragauskas, A. J., Richard, A. Dixon, R. A. (2015): Pinoresinol reductase 1 impacts lignin distribution during secondary cell wall biosynthesis in arabidopsis. - Phytochemistry 112(1): 170-178. 